\title{
The Father, the Son, and Obama
}

\author{
Jason Cooley ${ }^{1}$ \\ ${ }^{1}$ University of Hartford, West Hartford, USA \\ Correspondence: Jason Cooley, University of Hartford, 200 Bloomfield Avenue, West Hartford, CT 06117, USA. \\ E-mail: jacooley@hartford.edu
}

Received: May 29, 2013 Accepted: July 19, 2013 Online Published: August 30, 2013

doi:10.5539/jpl.v6n3p117 URL: http://dx.doi.org/10.5539/jpl.v6n3p117

\begin{abstract}
During the early 1990s, George H.W. Bush was being inundated with criticism since many individuals believed he had failed to devise an effective plan for bringing the United States out of a serious economic downturn. In the years following his time in the White House, some analysts continued to dwell on Bush's response to this recession, but there were others who elected to examine his performance in the international arena. Most of the evaluators of his foreign policy were of the opinion that he exercised great caution when he was dealing with developments on the world stage. While George W. Bush was running for president in 2000, it appeared as if he would be guided by this example that had been set by his father since he frequently scrutinized risky endeavors such as nation-building missions. However, once he won that election, a lot of comparisons could not be drawn between him and his father because he proceeded to introduce a rather ambitious agenda on the foreign front. From 2009 to the present, Barack Obama, the sitting U.S. president, has not attempted to accomplish lofty objectives as his predecessor did for eight years. Instead, he has opted to emulate the more circumspect approach of Bush's father. Inside the following article, this bond between Barack Obama and George H. W. Bush will be looked at in a thorough fashion.
\end{abstract}

Keywords: Barack Obama, George H.W. Bush, George W. Bush, Tiananmen Square Incident, pre-emptive strike

\section{Introduction}

At various points in American history, incoming presidents have attempted to distance themselves from their predecessors. It was usually deemed advantageous to do so because the former president had implemented policies on the foreign level that were quite unpopular with the general public. In 1952, Harry Truman could have run for another term in the Oval Office, but he elected not to because American involvement in the Korean War had made him an unappealing figure in the eyes of prospective voters. Dwight Eisenhower, the winner of the 1952 Presidential Election, was cognizant of the fact that he would lose the support of the American citizenry if he continued to prosecute the war, so one of the first major decisions that he made as president was agreeing to a cease-fire on the Korean Peninsula. The most recent example of a new president bringing an unpopular war to an end is Barack Obama's handling of the Iraq War. When Obama was running for president in 2008, he frequently criticized this conflict, which had commenced during the presidency of George W. Bush. He also said that he would work diligently to end it if he became the Forty-Fourth President of the United States. After he was sworn into office, he managed to keep this campaign promise by withdrawing the remaining U.S. soldiers who were situated in Iraq.

The decision from above does not make Obama look similar to George W. Bush. However, it does make him look like Bush's father. Within the upcoming pages, it will be possible to bolster this contention that Obama is reminiscent of George H. W. Bush by taking their responses to two prominent Chinese human rights abuse cases, the features of their main military campaigns and their handling of prospective Israeli military missions into consideration. The next section will be dedicated to their reactions to the Chinese cases.

\section{Bush and Obama's Responses to Human Rights Abuse Cases in China}

There are certain actions that frequently lead to international condemnation. More often than not, the parties, which are responsible for them, are states. The leaders of states have been subjected to scrutiny for both external and internal transgressions. A good example of the former triggering an international backlash is the 1990 Iraqi invasion of Kuwait. In the aftermath of this turn of events, the Iraqi government was barraged with criticism from a number of actors in the international community, including the United Kingdom. Margaret Thatcher, the British 
Prime Minister at the time, claimed that this invasion was "intolerable" during a press conference in the United States (Tisdall \& Hirst, 1990). Representatives of the British government have also been quick to criticize the internal transgressions of different governments. In 2011, David Cameron, the first Conservative Prime Minister since John Major, started to condemn the brutal tactics that were being utilized by the Syrian government during a popular uprising. He even took the time to release a joint statement with Nicholas Sarkozy, the President of France, and Angela Merkel, the Chancellor of Germany. Within it, Bashar al-Assad, the President of Syria, was encouraged to resign since there had been a "complete rejection of his regime by the Syrian people." (Cameron, Merkel, \& Sarkozy, 2011).

From the information in the preceding paragraph, it can be deduced that the states, which commit external and internal transgressions, are often maligned by other states in the international system. If we turn our attention to an incident within China towards the end of the 1980s, we will start to see how some states refrain from criticizing a nation in the aftermath of a particular transgression. In 1989, numerous demonstrators gathered in Beijing's Tiananmen Square. These individuals were hoping that this demonstration would result in the emergence of more political rights inside China, but it led to an undesirable outcome instead, which was an onslaught of government coercion. This reaction prompted many heads of state to criticize the members of China's communist regime. However, there were certain individuals who were reluctant to scrutinize these leaders in Beijing in the immediate aftermath of this incident. The most important in relation to this discussion is the American president George H.W. Bush.

In order to understand why Bush did not criticize the Chinese government, it is necessary to closely examine the state of U.S.-Sino relations around the time of the incident in Tiananmen Square. During the early stages of the Cold War, the United States government did not have a good rapport with the Chinese communists. In fact, American officials claimed that they were not the legitimate representatives of the Chinese people. According to them, the true leaders of the Chinese citizenry were the Chinese nationalists, a contingent that was forced to flee to Taiwan once the communists took power in 1949. This approach for dealing with China lasted until the early 1970s. It was at this juncture that Richard Nixon, the thirty-seventh President of the United States, traveled to China and met with various members of the communist government. In the aftermath of Nixon's historic visit, a degree of cooperation could actually be seen between Washington and Beijing.

At first, it was difficult for some in the U.S. to accept the above change. However, after more time elapsed, this sentiment began to dissipate since it was becoming quite clear that this arrangement was proving to be beneficial for the United States in the Cold War against the Soviet Union. When this conflict commenced, it was widely accepted that the U.S. was more powerful than the U.S.S.R. A number of developments eventually closed the power gap between these two nations, including the formation of an alliance between the Soviets and the Chinese communists in the 1950s. During the next decade, there was a split between the Soviets and the Chinese. This turn of events reduced the power of the Soviet bloc, but there was still a chance that this power could be regained if a rapprochement transpired between Moscow and Beijing (Hyer, 1996, p.4). The emergence of cooperation between the Chinese and the Americans after the Nixon visit in the 1970s decreased the likelihood that this Sino-Soviet rapprochement would happen.

George H.W. Bush feared condemning China's response to the Tiananmen Square Incident would jeopardize this progress that had been made on the security front. The experience of a previous president suggests he was correct to presume that emphasizing human rights could adversely impact the United States. When Jimmy Carter became president in 1977, there were multiple goals that he wanted to achieve on the foreign level. One, which received a considerable amount of attention, was his desire to increase the rights of individuals living under oppressive regimes in other nations (Kissinger, 2011, p.378). At the time, a number of the governments that were preventing civilians from exercising important rights such as the freedom of speech were aligned with the United States in the Cold War against the Soviet Union. So if Carter confronted them about their abysmal human rights records, there was a chance that they would sever their ties with the U.S. and become members of the communist bloc. One must conclude that this possibility was on Carter's mind from time to time. After all, various allies, which were known for being violators of human rights, were never encouraged to implement reforms by representatives from the Carter administration, including the Shah of Iran and President Park Chung Hee in South Korea (Halliday, 1986, p.227). Some of the allies that were pressured about their human rights records did make the decision to switch from the capitalist to the communist bloc. A case that can be used to illustrate this crucial point is the government of Ethiopia. During 1977, Carter elected to cut off military assistance to this regime because of human rights violations. Shortly after this turn of events, Addis Ababa became the recipient of aid from the Soviet Union and Cuba (Halliday, 1986, p.222). 
While George H.W. Bush was not willing to publicly condemn the members of the communist regime in Beijing, he was in favor of making a number of discreet moves that were designed to show these individuals that America disapproved of the brutal response to the demonstration, including suspending high-level government exchanges and halting the selling of police, military, and dual-use equipment to the Chinese (Kissinger, 2011, p.416). Maneuvers like these did not placate legislators who were convinced that the U.S. needed to react to the Tiananmen Square Incident in a confrontational fashion. On June 6, 1989, two days after the incident transpired, resolutions were passed unanimously in both the U.S. House of Representatives and Senate that urged "the President to strongly condemn China." (Hyer, 1996, p.1). Bush did not issue any statements with derogatory comments about the communist regime once these resolutions were passed, but this did not lead to a decline in Congressional pressure. Eventually, the House and Senate began to pass various pieces of legislation that were intended to punish the Chinese government for its egregious conduct. Usually, an American President will choose to modify his position regarding a major foreign policy issue as Congressional pressure increases. This can be seen if the behavior of George H.W. Bush's predecessor is taken into consideration. During the early portion of the 1980s, a dispute transpired between Ronald Reagan and legislators over U.S. troops in Lebanon. Reagan was keen on keeping these soldiers in this Middle Eastern nation. Members of Congress, on the other hand, wanted them to be withdrawn as soon as possible. When this battle commenced, it seemed as if Reagan would never change his opinion. However, as Congressional pressure continued to mount, he agreed to bring the Lebanese mission to an end. If we turn our attention back to the latter portion of the 1980s, it will be possible to notice how George H.W. Bush handled Congressional pressure in a different manner. Rather than succumbing to the legislative branch like Reagan did, Bush opted to maintain his original approach for dealing with the Chinese government's internal misconduct. In other words, he continued to refrain from engaging in provocative activities that could possibly jeopardize the major benefit being generated by American-Chinese cooperation. Something, which can help strengthen this point, is the way he reacted to the two major bills that had been passed in Congress. Towards the end of 1989, he vetoed a State Department appropriations bill and a bill that was sponsored by Nancy Pelosi, a Congresswoman from California. The former called for tough sanctions against China. Meanwhile, the latter provided Chinese students in the United States with political asylum (Hyer, 1996, p.9).

Political activists continued to be abused by the Chinese government in the years following the incident in Tiananmen Square. However, most of these cases were overlooked by actors abroad. One of the few cases, which actually generated a considerable amount of international intrigue, was the mistreatment of a blind activist named Chen Guangcheng. Chen was imprisoned for several years because he frequently criticized the government's treatment of women and the controversial policy that prevented Chinese families from having more than one child (Mascardo \& Demick, 2012). Once he was released from prison in the fall of 2010, Chinese officials kept him under house arrest in Dongshigu, a small village in the eastern province of Shandong. During this house arrest, Chen and his wife were allegedly beaten by the security personnel who were situated near their home (Johnson \& Ansfield, 2011).

As reports about this mistreatment began to spread abroad, the Chinese government was subjected to a lot of scrutiny. However, there were some international leaders who refrained from criticizing the members of the communist regime, including the American President Barack Obama. Earlier in this section, it was noted how George H.W. Bush's refusal to condemn Chinese officials in the aftermath of the Tiananmen Square Incident upset various politicians within the United States. Obama's handling of the Chen case did not initially infuriate any American political figures, but some critics started to surface during the middle portion of 2012. At this juncture, Chen escaped from the house in Dongshigu and traveled to the American embassy in Beijing. When the American State Department only allowed him to remain at this facility for a short period of time, multiple Republicans made negative comments about Obama. The most vocal of these critics was Mitt Romney, the Republican nominee for the 2012 Presidential Election. In the middle of a speech on the campaign trail, he said: "And it's a day of shame for the Obama administration. We are a place of freedom, here and around the world, and we should stand up and defend freedom whenever it is under attack." (Romney, 2012). Although Obama was criticized by individuals from a rival party, he never had to deal with the passage of major Congressional resolutions and bills in relation to the Chen case. This is obviously an indication that the internal backlash against him was not as bad as the one that George H.W. Bush faced towards the end of the 1980s.

During the discussion about the Tiananmen Square Incident, attention was paid to how Bush feared that criticizing the Chinese government might jeopardize the security benefit, which had emerged since the commencement of Sino-American cooperation. At the time of the Chen case, Obama was also interested in preserving an important benefit that was being produced by cooperation between China and the United States. However, it must be emphasized that this benefit did not pertain to the security realm. Towards the end of 1982, Richard Nixon made a 
private trip to China. After he returned from this visit, he sent a letter about the future of Chinese-American relations to President Reagan. Within it, he asserted that economics could draw these two nations closer together in the future (Nixon, 1982). Once the Soviet threat vanished in the early 1990s, it became possible for China and the United States to focus more on strengthening their economic ties. By 2004, America was actually "the second largest trading partner of China, and China was the fourth largest trading partner and rapidly growing export market for the United States." (Khairul Islam, 2006, p.27).

This access to the Chinese market became even more important when Obama was in power since America was experiencing its worst economic downturn since the Great Depression. If officials in Beijing opted to cut off American access to the Chinese market, this malaise would have just worsened since key U.S. companies would have been unable to sell as many of their products. Some corporations respond to declining sales by going out of business. Meanwhile, others remain open and begin to make substantial spending cuts. An inevitable consequence of both of these developments would have been U.S. workers losing their jobs. This, of course, would have increased the U.S. unemployment rate, which had already climbed over eight percent during Obama's time in office.

Obama placed the American economy above the mistreatment of a Chinese dissident. However, it would be inappropriate to assume that he never did anything to ameliorate the living conditions of Chen since American officials eventually allowed this activist to travel to the United States and work at New York University's School of Law (Mascardo \& Demick, 2012). This turn of events suggests that Obama was concerned about the lack of political rights within China to a certain extent. It is possible to label this as another link between Obama and George H.W. Bush. After all, the latter managed to exhibit a limited interest in this topic at the time of the Tiananmen Square Incident by making discreet moves such as suspending high-level government exchanges between China and the United States (Kissinger, 2011, p.416).

\section{Features of Bush and Obama's Major Military Campaigns}

Within the introductory portion of this article, an unpopular American military operation in Iraq was mentioned. There were several reasons why the Iraqi mission was unpopular inside the United States. The one that will be focused on in this discussion is the way it was conducted by George W. Bush. International leaders occasionally contemplate utilizing force to accomplish foreign policy objectives. Most of them will only proceed with a military operation if it is deemed to be legitimate by the international community. The most popular method for securing international approval for an initiative is having the members of the United Nations Security Council pass a resolution. Individuals inside the Bush administration attempted to get this body to pass a resolution authorizing the utilization of coercion against Iraq in the early part of 2003. However, a resolution was never approved because most of the members were opposed to this course of action. When Bush eventually decided to embark on the military campaign in Iraq without authorization from the United Nations, a lot of American citizens began to criticize him. This turn of events did not come as much of a surprise since prior polls had indicated that most individuals would only be willing to support a mission that was sanctioned by the United Nations. For example, in a Gallup Poll from November 2002, the majority of the respondents agreed that the United States should only invade Iraq if a Security Council Resolution was passed beforehand (Gallup, 2002).

Something else, which was scrutinized within the United States, was the length of the Iraqi mission. In the aftermath of the Vietnam War, several U.S. officials wanted to avert other endless or indefinite military campaigns. Some even suggested that future American operations should consist of exit strategies. One of the most prominent advocates of this proposal was Colin Powell, George W. Bush's first Secretary of State. It can be said that Powell did not have much of an impact on the formulation of policy during the Iraqi operation. After all, his superior did not display an affinity for establishing a withdrawal date for U.S. soldiers (Nye, 2004, p.112). Since Bush was reluctant to create a timetable for the removal of these troops, numerous Americans started to see the Iraqi operation as another Vietnam. Certain individuals elected to display their support for this perspective by placing bumper stickers on their cars that said "Iraq is Arabic for Vietnam."

Barack Obama's decision to bring the Iraqi mission to an end made him look like a Commander-in-Chief who was opposed to military campaigns that were indefinite and internationally illegitimate. However, this was not the only choice from his presidency that allowed him to develop this reputation. Two years after Bush left the White House, a military operation transpired in Libya that was both internationally legitimate and succinct. In the second to last page, it was noted how the most popular way to legitimize a military operation on the world stage is by having the United Nations Security Council pass a resolution. The American operation in Libya was preceded by this turn of events. The members of the Security Council were in favor of utilizing force in this North African nation because the regime of Moammar el-Gaddafi was killing civilians during an internal uprising. One becomes cognizant of 
their concern about the treatment of civilians while examining different portions of the approved resolution. For example, at one point, they said all necessary measures could be taken "to protect civilians and civilian populated areas under threat of attack in the Libyan Arab Jamahiriya" (United Nations Security Council Resolution, 2011). The preferred measure of the United States was establishing a no-fly zone inside Libya. There were other nations that were willing to assist with the completion of this task, including Great Britain and France. These two countries helped America by dropping bombs on military equipment that was being used by soldiers in the Libyan military.

It did not take America and its European allies very long to establish the no-fly zone. When this objective was accomplished, the Europeans began to play a bigger role in the Libyan mission. In fact, the United States eventually allowed them to assume the responsibility of maintaining the no-fly zone. Since this leadership change transpired, it became possible for President Obama to reduce American involvement in the Libyan air campaign. By the middle portion of 2011, American participation in the air campaign was limited to providing refueling and surveillance for the European planes that were in the process of preserving the no-fly zone (Savage \& Landler, 2011). These forms of assistance were only needed for a brief period of time since European flights came to an end later in 2011.

From the material in the last two paragraphs, it can be gathered that Obama conducted military operations much differently than George W. Bush. If some more information about the Libyan mission is taken into consideration though, we will start to see how these two presidents actually share an important similarity. While this campaign was in progress, President Obama made various decisions that indicated he also wanted to help the insurgents topple the Gaddafi regime. Among them was signing a secret document that allowed "the CIA to provide arms and other support" to these individuals (Mazzetti \& Schmitt, 2011). Because this assistance was being provided, it can be said that the Libyan mission resembled the initiative in Iraq. After all, the main objective of this 2003 operation was to overthrow Saddam Hussein, another undesirable Arab leader. Leadership change was being emphasized during both of these operations, but the covert allocation of weapons and other supplies to insurgents within Libya demonstrates that Obama did not possess an affinity for George W. Bush's preferred method for producing leadership change. In other words, it shows that he was not in favor of launching a full-scale military invasion to remove an unwanted leader from power.

Twelve years before members of the American military invaded Iraq, George H.W. Bush launched another military attack that was designed to bring the Iraqi occupation of Kuwait to an end. As one begins to examine the major features of this attack, one begins to realize that George H.W. Bush conducted military operations like Barack Obama did. We have seen how the operation in Libya was preceded by the passage of a United Nations Security Council Resolution. This same body approved another resolution towards the end of 1990, which said that "all necessary means" could be used to liberate Kuwait (United Nations Security Council Resolution, 1990). Since this measure was passed, the 1991 military campaign against Iraq came to be seen as a legitimate initiative on the world stage.

In addition to being internationally legitimate, the 1991 mission was quite brief. It commenced in the middle of January with an intense bombing campaign by American and European warplanes (Bush \& Scowcroft, 1998, p.451). This campaign was followed by a major ground offensive in Kuwait. Personnel from European nations also participated in this portion of the 1991 mission, but the majority of the soldiers were from the United States. Shortly after these individuals moved inside Kuwait, it was announced that a considerable amount of Iraqi soldiers were beginning to retreat to their native country (Bush \& Scowcroft, 1998, p.483). Since this turn of events transpired, Bush was able to move numerous U.S. troops out of the Middle East. In fact, on March $10^{\text {th }}$, over 500,000 soldiers left this region. A complete withdrawal could not take place at this juncture because Bush and some other leaders in the Middle East feared that Hussein would resort to aggression again in the future.

The 1991 effort to liberate Kuwait was succinct and internationally legitimate like the 2011 mission in Libya, but a crucial difference did exist between these initiatives. Earlier in this section, it was mentioned how the Obama administration also used the Libyan operation to help the insurgents who were attempting to overthrow the regime of Moammar Gaddafi. Towards the end of the 1991 operation in the Middle East, certain parties inside Iraq began to work assiduously to topple the government of Saddam Hussein. The argument could be made that this uprising was partially triggered by George H.W. Bush. After all, during the latter stages of the U.S. campaign, he declared over an American propaganda outlet that: "There is another way for the bloodshed to stop: And that is, for the Iraqi military and the Iraqi people to take matters into their own hands and force Saddam Hussein, the dictator, to step aside" (George H.W. Bush, 1991). Usually, a leader will elect to provide individuals, who he or she has encouraged to rebel, with covert assistance once the insurgency starts. However, this turn of events did not transpire once the Iraqi rebellion commenced in 1991. Instead, Bush opted to refrain from supporting the rebels who were eager to generate political change. 
Most Americans did not object to the decision to refrain from pursuing leadership change in Iraq after the liberation of Kuwait. Still, it is worth noting how some were quite critical of this choice. The majority of these critics were not interested in using the above Iraqi insurgents to topple the Hussein regime. Rather, they were convinced that soldiers from the United States and other nations should complete this task. Within the 1998 release A World Transformed, George H.W. Bush and Brent Scowcroft, his National Security Advisor at the time of the 1991 mission, discussed why they did not attempt to overthrow Hussein in an overt fashion. While one reads through the pages of this publication, one starts to recognize that these men were reluctant to proceed with this course of action because they believed that several unappealing outcomes would follow, including a prolonged occupation of Iraq (Bush \& Scowcroft, 1998, p.489). When developments like this one actually transpired after Hussein was removed from power by American soldiers in 2003, it became quite apparent that Bush and Scowcroft were wise to be so cautious back in 1991.

\section{Bush and Obama's Responses to Prospective Israeli Military Campaigns}

Over the years, the world has witnessed the termination of a number of alliances between the United States and other nations. Some of these alliances have ended because of changes in the international system. One of the most notable alliances, which concluded after an alteration on the world stage, was the U.S.-Soviet alliance from the 1940s. Individuals in Washington and Moscow began to work together during the early portion of this decade because they were determined to halt fascist expansion in areas such as Asia and Europe. At the time, there were multiple developments that indicated this alliance was in the process of being established. Among them was the allocation of a substantial amount of U.S. military aid to the Soviet Union in 1941. It was imperative for the Soviets to receive this assistance since a full-scale German invasion of the Soviet Union was in progress. Once Germany and the other fascist powers were defeated in 1945, the American-Soviet alliance began to fall apart. By the end of the 1940s, they would be competing against each other in the Cold War.

At times, alliances have come to an end because of leadership changes. A good example of leadership change resulting in the termination of an alliance is the Cuban Revolution. Before this uprising transpired, Washington possessed a solid rapport with Havana. This positive relationship mainly surfaced because every Cuban leader since the start of the twentieth century had kept the Cuban economy open to outside actors such as American corporations. When Fidel Castro began to block American access to the Cuban economy through the process of nationalization in the immediate aftermath of the revolution, U.S. officials were quite upset (Brussel, 1992, p.26). However, this would not be the only change that infuriated these figures. Eventually, Castro decided to establish a close relationship between Cuba and the Soviet Union. This was obviously something that U.S. foreign policymakers did not want to see happen since America was competing against the latter in the Cold War. Several covert missions were organized in Washington that were designed to engineer another leadership change in Havana, but none of them resulted in the rise of a new leader who was receptive to reopening Cuban markets to outside parties and bringing an end to the threatening alliance with the Soviet Union.

Certain alliances have actually managed to withstand leadership changes. The most important in relation to this discussion is the American-Israeli alliance. No leadership changes have brought about the termination of this alliance, but there have been occasions when they have resulted in disputes. In the aftermath of an American leadership change in the late 1980s, one of the most serious American-Israeli disputes transpired. During the 1980s, Reagan became known as a strong supporter of Israel in various circles. One of the most important contingents, which looked at him in this fashion, was the group of Arab countries that refused to recognize Israel as a legitimate state. At one point, the king in one of these nations even said: "You've obviously made your choice and your choice is Israel and support of Israel." (Hussein, 1984). Reagan primarily developed this reputation by making decisions that helped Israel defend itself against these Arab adversaries. Without question, the most important one was increasing the amount of military assistance that Israel was receiving from the United States (Spiegel, 1985, p.400).

After Bush gained control of the executive branch in 1989, it became quite apparent that he would not be viewed as a close supporter of Israel like his predecessor. At the beginning of 1991, officials in Tel Aviv wanted to carry out an attack against Iraq so that this Arab nation would not be able to launch more Scud missiles at Israel. The members of the Bush administration were opposed to an Israeli campaign because they feared that it would make it more difficult for the United States to accomplish another objective. During the last section, attention was paid to how the United States became involved in a military campaign to remove Iraqi forces from Kuwait in the early 1990s. What was not mentioned in this section was the fact that a number of Arab nations were assisting the United States with this initiative. If an Israeli attack against Iraq transpired, there was a chance that this campaign would be adversely impacted since these Arab nations might elect to abandon the coalition in order to fight with the Iraqis against the Israelis. 
Within Warring Friends: Alliance Restraint in International Politics, Jeremy Pressman discusses how nations will often attempt to keep allies from embarking on military missions. On occasion, some leaders have engaged in extensive negotiations with officials from the governments that are considering the utilization of coercion so that this desired outcome can be generated. The members of the George H.W. Bush administration actually used this technique when the Israelis were contemplating an assault against Iraq. During several American-Israeli sessions, the representatives from the Bush administration asserted that some of the U.S. ground and aerial forces in the Kuwaiti operation could be used to attack the launching sites for Iraq's Scud missiles. It can be said that the introduction of this proposal mollified the Israelis since talk of a retaliatory strike against Iraq eventually began to dissipate. This diplomatic initiative in the early portion of 1991 prevented the Israelis from disrupting the effort to liberate Kuwait (Pressman, 2008, p.1). However, it was also followed by some undesirable developments, including the surfacing of a considerable amount of tension between the United States and Israel. One begins to notice this tension while looking at an entry that Bush made in his diary after meeting with a figure from the Israeli government. At one point in this entry, he said: "I was annoyed when he said Israel could do things we could not to destroy the Scuds in Western Iraq, and irritated that the Israelis, or at least the hard-liners, seemed to offer so little thanks for what we were trying to accomplish for them." (Bush, 1991).

This tension began to decline once Bush left office. In fact, his son came to be known as another close friend of the Israeli government. Earlier in this section, it was noted how Reagan primarily developed a reputation as a strong Israeli supporter by sending more military assistance to Tel Aviv. There was another substantial increase in U.S. aid to Israel when George W. Bush was in power. Something else, which allowed George W. Bush to be viewed as a strong supporter of Israel, was his response to the 2006 war between Israel and Lebanon (Mearsheimer \& Walt, 2007, p.26). While this conflict was in progress, there were various reports that Israeli operations were leading to the deaths of numerous Lebanese civilians. Many leaders in the international community condemned the Israeli government after coming into contact with this information. However, Bush did not criticize the officials in Tel Aviv. Instead, he ended up “openly defending Israel's behavior." (Mearsheimer \& Walt, 2007, p.8).

Barack Obama did not exhibit the same support for Israeli military missions as his predecessor. There was even one occasion when he attempted to restrain the Israelis. He, of course, cannot be labeled as the first American president who attempted to restrain this nation since George H.W. Bush worked to keep the Israelis from attacking Iraq in the early 1990s. Barack Obama was more concerned about an Israeli attack against Iran. During his first term in office, various media outlets reported that Benjamin Netanyahu, the Israeli Prime Minister, was seriously considering a military campaign against this non-Arab nation in the Middle East. An attack was deemed to be a necessity by the Israeli leader because Mahmoud Ahmadinejad, the President of Iran, was in the process of developing weapons of mass destruction. Netanyahu feared that these weapons would be launched against Israel because the Iranian President once said that this nation should be "wiped off the face of the earth." (Ahmadinejad, 2005). From the information in the preceding sentences, it can be gathered that Netanyahu and his advisors were in a much different position than the Israeli officials who were contemplating the utilization of military force while George H.W. Bush was president. On the one hand, the leaders from the early 1990s were thinking about conducting a retaliatory strike. On the other, the members of the Netanyahu administration were pondering the execution of a pre-emptive strike.

Pre-emptive strikes can be viewed as legitimate if an attack against a particular nation is imminent. However, there was no evidence indicating that officials from the Islamic Republic were close to performing a strike against Israel. Instead, it was widely believed that they were having difficulty producing weapons of mass destruction (Ignatius 2012). This Iranian initiative was turning out to be arduous because multiple parties in the international community were taking various steps to undermine the production process. The main actor, which was responsible for organizing these efforts, was the United States. In addition to imposing tougher sanctions on Iran, President Obama authorized various clandestine operations that were designed to sabotage Iran's weapons program. A rather effective covert operation was the unleashing of a virus in different computers that were associated with the Iranian nuclear program. It caused several centrifuges to spin "at faster-than-normal speeds until sensitive components began to warp and break" (Nakashima \& Warrick, 2012).

The lack of progress within Iran did not placate the Israelis. In fact, during 2012, talk of an Israeli attack against Iran began to increase. This also proved to be a critical juncture because there were signs that the members of the Obama administration were finally attempting to restrain Israel. Earlier in this section, we saw how representatives from the Bush administration tried to prevent an Israeli military operation against Iraq by participating in a series of meetings with Israeli officials. The members of the Obama administration utilized this approach as well. Initially, individuals from the State and Defense Departments were given the responsibility of meeting with the Israelis about a potential strike in Iran. However, once more time elapsed, President Obama became personally 
involved in this diplomatic initiative. At the beginning of March, he met with Netanyahu at the White House. Shortly after this meeting transpired, it was widely reported that Netanyahu agreed to postpone an attack against Iran until after the 2012 American Presidential Election in exchange for sophisticated American weaponry (AFP, 2012).

The material towards the end of the last paragraph is quite significant. After all, it indicates that Bush and Obama were eager to restrain Israel for much different reasons. In the preceding pages, we learned that the diplomatic initiative during the Bush years was designed to accomplish a major goal on the international level, which was keeping the Israelis from disrupting the effort to liberate Kuwait. Obama was not determined to achieve something on the foreign level. Instead, he possessed an important domestic objective, which was preventing an Israeli attack from adversely impacting his bid to secure a second term in the Oval Office.

\section{Conclusion}

Some believe that "the son rises and sets like the father." There have been occasions when this has happened in the political realm. Still, several sons have failed to behave like their fathers after they have assumed control of certain offices that were once occupied by the men who raised them. We had an opportunity to examine one of these individuals in the preceding pages. George W. Bush was fortunate enough to win the first American presidential election of the twenty-first century. However, after he came to power, he began to make various decisions on the foreign level that were unwise, especially embarking on a prolonged military campaign in Iraq that was not sanctioned by an international body like the United Nations. This can definitely be regarded as something that set him apart from his father. After all, while George H.W. Bush was in office towards the end of the twentieth century, the United States conducted a military operation in the Middle East that was succinct as well as internationally legitimate.

It cannot be said that George W. Bush followed in his father's footsteps. However, one can make the claim that his successor has since three significant connections were made between the presidencies of Barack Obama and George H.W. Bush in this article. Within one section, it was noted how Barack Obama and George H.W. Bush both refrained from criticizing the Chinese government in the aftermath of prominent human rights abuse cases because they feared that such a reaction would harm American interests. Following this discussion, we turned our attention to the fact that Barack Obama also conducted a military campaign that was brief and internationally legitimate. Of course, the last similarity, which was touched upon in the body of the article, was the way that Barack Obama and George H.W. Bush worked assiduously to restrain Israel when it was on the verge of attacking Iran and Iraq.

\section{References}

AFP. (2012, March 9). US, Israel 'Made Secret Iran Deal.' The Daily Telegraph. http:/www/dailytelegraph.com.au/peace-deal-gives-israel-new-bombs/story-fn6elm72-1226294301079.

Ahmadinejad, M. (2005). Comments Made about the Nation of Israel.

Brussel, G. (1992). The Cuban Missile Crisis: U.S. Deliberations and Negotiations at the Edge of the Precipice. Washington: Institute for the Study of Diplomacy.

Bush, G. H. W. (1991a). Diary Entry about a Meeting with an Israeli Official.

Bush, G. H. W. (1991b). Message Encouraging Iraqis to Stage a Rebellion against Saddam Hussein.

Bush, G. H. W., \& Scowcroft, B. (1998). A World Transformed. New York: Alfred A. Knopf.

Cameron, D., Merkel, A., \& Sarkozy, N. (2011). Joint Statement about the Conflict in Syria.

Gallup News Service. (2002, November 12). Poll in the United States about an Invasion of Iraq.

Halliday, F. (1986). The Making of the Second Cold War. London: Verso.

Hyer, E. (1996). Values versus Interests: The U.S. Response to the Tiananmen Square Massacre. Washington: The Institute for the Study of Diplomacy.

Ignatius, D. (2012, July 1). Israelis Weigh Military Action against Iran. Hartford Courant, C3.

Islam, K. (2006). The Post-Cold War U.S.-China Relations: Win-Win or Zero-Sum Game. Asian Affairs, 28, 24-45.

Johnson, I., \& Ansfield, J. (2011, June 17). Chinese Officials Beat Activist and His Wife, Group Says. New York Times. Retrieved from http://www.nytimes.com/2011/06/18/world/asia/18china.html

King Hussein bin Talal of Jordan. (1984, March 15). Comments Made about Ronald Reagan. 
Kissinger, H. (2011). On China. New York: Penguin Press.

Mascardo, L., \& Demick, B. (2012, May 20). Amid Diplomatic Drama, Chinese Activist Now in U.S. Hartford Courant, A13.

Mazzetti, M., \& Schmitt, E. (2011, March 30). CIA Personnel Operating in Libya, Officials Say. New York Times. Retrieved from http://www.boston.com/news/world/africa/articles/2011/03/31/cia_personnel_operat ing_in_libya_officials_say/

Mearsheimer, J., \& Walt, S. (2007). The Israel Lobby and U.S. Foreign Policy. New York: Fartar, Straus, and Giroux.

Nakashima, E., \& Warrick, J. (2012, June 1). Stuxnet Was Work of U.S. and Israeli Experts, Officials Say. Washington Post. Retrieved from http://www.washingtonpost.com/world/national-security/stuxnet-waswork-of-us-and-israeli-experts-officials-say/2012/06/01/gJQA1DEy64.story.html

Nixon, R. (1982). Letter to President Reagan Regarding the Future of Sino-American Relations.

Nye, J. (2004). Soft Power. Cambridge: Perseus Book Group.

Pressman, J. (2008). Warring Friends: Alliance Restraint in International Politics. Ithaca: Cornell University Press.

Romney, M. (2012, May 3). Comments Made about President Obama at a Campaign Rally in Portsmouth, Virginia.

Savage, C., \& Landler, M. (2011, June 15). White House Defends Continuing U.S. Role in Libya. New York Times. Retrieved from http://www.nytimes.com/2011/06/16/US/politics/16powers.html?pagewanted=all

Spiegel, S. (1985). The Other Arab-Israeli Conflict. Chicago: University of Chicago Press.

Tisdall, S., \& Hirst, D. (1990, August 3). Superpowers Unite on Iraq. The Guardian. Retrieved from http://www.guardian.co.uk/world/1990/aug/03/iraq.davidhurst/print

United Nations. (1990). Security Council Resolution 678.

United Nations. (2011). Security Council Resolution 1973.

\section{Copyrights}

Copyright for this article is retained by the author(s), with first publication rights granted to the journal.

This is an open-access article distributed under the terms and conditions of the Creative Commons Attribution license (http://creativecommons.org/licenses/by/3.0/). 